\title{
New Spirinia and Stygodesmodora species (Nematoda, Spiriniinae) from the Southwest Pacific, and a revision of the related genera Spirinia, Chromaspirina and Perspiria
}

\author{
Daniel LEDUC ${ }^{1,3}$ \& Dominick VERSCHELDE ${ }^{2,4}$ \\ ${ }^{1}$ National Institute of Water and Atmospheric Research, Private Bag 14-901, Wellington, New \\ Zealand. Correponding author: Daniel.Leduc@niwa.co.nz \\ ${ }^{2}$ Ghent University - Zoology Museum, K.L. Ledeganckstraat 35, B-9000 Ghent, Belgium \\ ${ }^{3}$ urn:1sid:zoobank.org:author:9393949F-3426-4EE2-8BDE-DEFFACE3D9BC \\ ${ }^{4}$ urn:Isid:zoobank.org:author:80C09028-E083-4DF0-B514-9C92A12ED78E
}

\begin{abstract}
Two new species of the family Desmodoridae are described from the upper continental slope of New Zealand, Southwest Pacific, and the genera Spirinia, Chromaspirina and Perspiria are revised. Spirinia verecunda sp. nov. is characterised by a short, stout body, cuticle covered in minute, hair-like structures, unispiral amphideal aperture and cryptospiral amphideal fovea, buccal cavity with small dorsal tooth and minute subventral teeth, eight oblong glands surrounding anterior portion of pharynx, large sperm cells, spicules with weak capitulum, and the absence of precloacal supplements. Stygodesmodora confusa sp. nov. is characterised by a relatively short body, spiral amphids with 1.21.4 turns, cephalic setae situated at or slightly posterior to mid-level of amphid, and males with four precloacal supplements consisting of short setae on wide bases. Like other species of the genus, S. confusa sp. nov. is characterised by an annulated head region, but in some specimens the cuticle annulations are restricted to the dorsal and ventral sides of the head. $S$. confusa sp. nov. shows similarities with species of other desmodorid genera (i.e., Echinodesmodora, Bolbonema), but can be differentiated from them by the presence of an annulated head region and amphideal plates. The genera Spirinia, Chromaspirina and Perspiria have very similar morphologies and differ mainly in the size and structure of the buccal cavity (Spirinia vs Chromaspirina) or the shape of the tail and placement of the amphids relative to the cuticle annulations (Spirinia vs Perspiria); their diagnoses are clarified and some nomenclatural changes are proposed to eliminate overlap in the definitions of these genera.
\end{abstract}

Keywords. Desmodoridae, deep-sea, meiofauna, Chatham Rise, southern Hikurangi Margin

Leduc D. \& Verschelde D. 2015. New Spirinia and Stygodesmodora species (Nematoda, Spiriniinae) from the Southwest Pacific, and a revision of the related genera Spirinia, Chromaspirina and Perspiria. European Journal of Taxonomy 118: 1-25. http://dx.doi.org/10.5852/ejt.2015.118

\section{Introduction}

Spirinia Gerlach, 1963 is a relatively common genus and twelve valid species have been described to date (Silva et al. 2009). Spirinia is very similar to Chromaspirina Filipjev, 1918 in the shape and structure of 
the head region, amphids, pharynx, and male copulatory apparatus. The main distinction between the two genera is the shape of the buccal cavity: Spirinia is characterised by a narrow and lightly cuticularised buccal cavity with no or a small dorsal tooth and no or minute subventral teeth, whereas Chromaspirina is characterised by a more heavily cuticularised, medium to large buccal cavity with a large dorsal tooth and smaller subventral teeth. A third genus, Perspiria Wieser \& Hopper, 1967, is also similar to Spirinia and differs from the latter in having a conico-cylindrical to filiform tail and by the amphids not completely surrounded by body annulations. Species of these three genera show considerable overlap in the above-mentioned morphological characteristics, however, and the boundaries between them have become somewhat blurred. Here, we describe $S$. verecunda sp. nov. from the Chatham Rise crest (350 m water depth) on the continental margin of New Zealand, and we propose several nomenclatural changes to species of Spirinia and Chromaspirina to allow a more consistent distinction between the genera based on buccal morphology. Several nomenclatural changes are also suggested for the genus Perspiria to reflect differences in tail shape and body annulations of the head region between the latter genus and Spirinia.

Stygodesmodora Blome, 1982 is a relatively uncommon genus comprising only two species: $S$. bacillicauda (Gerlach, 1963) and S. epixantha Blome, 1982. These species were described from shallow sandy sediments in the Indian Ocean and North Sea, respectively. Here a third species, S. confusa sp. nov., is described from the continental margin of New Zealand (350 and $686 \mathrm{~m}$ water depth); it is the first species of the genus to be described from the deep sea.

\section{Material and Methods}

Samples for species descriptions were obtained from the Chatham Rise and southern Hikurangi margin, Southwest Pacific. The Chatham Rise is a submarine ridge that extends eastwards from the South Island of New Zealand, over water depths ranging from $c a$. 250 to $3000 \mathrm{~m}$. The highly productive Subtropical Front (STF) is geographically constrained near the southern flank of the rise at around $44^{\circ} \mathrm{S}$ (Murphy et al. 2001). The southern Hikurangi margin lies on the south-eastern extremity of the North Island of New Zealand and is situated north of the Chatham Rise. Samples were collected at two sites: one situated near the head of a canyon on the southern Hikurangi margin during National Institute of Water and Atmospheric Research (NIWA) cruise TAN1004 (station 92, $686 \mathrm{~m}$ water depth, $41.8921^{\circ} \mathrm{S}, 174.6347^{\circ}$ E), and one at an open slope site located near the central Chatham Rise crest during NIWA cruise TAN1103 (station $69,350 \mathrm{~m}$ water depth; $43.331^{\circ} \mathrm{S}, 178.288^{\circ} \mathrm{E}$ ).

Sediment samples were collected using an Ocean Instruments MC-800A multicorer (MUC; core internal diameter $=9.52 \mathrm{~cm}$ ). Each sample consisted of one subcore of internal diameter $26 \mathrm{~mm}$ taken to a depth of $5 \mathrm{~cm}$. Samples were fixed in 10\% formalin and stained with Rose Bengal. Samples were subsequently rinsed on a $1 \mathrm{~mm}$ sieve to remove large particles and on a $45 \mu \mathrm{m}$ sieve to retain nematodes. Nematodes were extracted from the remaining sediments by Ludox flotation and transferred to pure glycerol (Somerfield \& Warwick 1996). Species descriptions were made from glycerol mounts using differential interference contrast microscopy, and drawings were made with the aid of a camera lucida. Specimens for scanning electron microscopy (SEM) were transferred to a $2 \%$ glutaraldehyde solution with sodium cacodylate buffer overnight, then transferred to a $4 \%$ osmium tetroxide solution for 2 hours. They were then gradually transferred to pure ethanol using a graded ethanol series, critical point dried, and mounted onto stubs before being coated with gold using a sputter coater. Observations were made using a Hitachi TM3000 tabletop SEM at high vacuum mode.

All measurements are in $\mu \mathrm{m}$, and all curved structures are measured along the arc. Type specimens are held in the NIWA Invertebrate Collection, Wellington, New Zealand. Abbreviations in the text are as follows: 


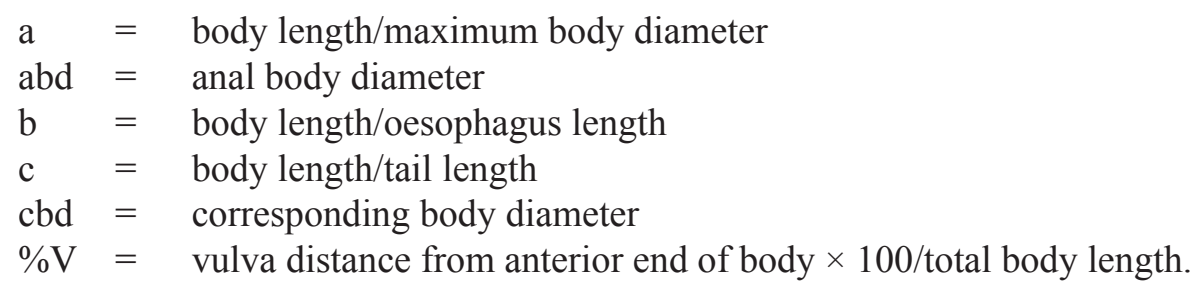

\section{Results}

Phylum Nematoda Cobb, 1932

Class Chromadorea Inglis, 1983

Subclass Chromadoria Adamson, 1987

Order Desmodorida de Coninck, 1965

Suborder Desmodorina de Coninck, 1965

Superfamily Desmodoroidea Filipjev, 1922

Family Desmodoridae Filipjev, 1922

\section{Type genus}

Desmodora de Man, 1889 (synonym: Mastodex Steiner, 1921).

Emended diagnosis (modified from Lorenzen 1981 and Decraemer \& Smol 2006)

Member of Desmodoroidea. Cuticle with coarse annulations, at least in anterior body region, or striated. Specialised somatic setae, such as adhesion tubes (Draconematidae) or ambulatory setae (Epsilonematidae) not present. Amphideal fovea usually spiral, unispiral, cryptospiral, or cryptocircular, and sometimes loop- or pore-shaped. Buccal cavity with small to large dorsal tooth and smaller or indistinct subventral teeth. Pharynx usually with round muscular posterior bulb, with or without cuticularised lumen; sometimes bulb is pyriform, elongated, or indistinct. Gubernaculum without dorsal apophyses. Males usually monorchic, except in Onepunema Leduc \& Verschelde, 2013 (diorchic). Vulva usually posterior to middle of body. Tail conical.

\section{Remarks}

Armenteros et al. (2014) recently argued that the genus Onepunema Leduc \& Verschelde, 2013 is more closely related to the Microlaimidae than to the Desmodoridae because of the presence of two testes (a feature common in the former but not found in the latter). The Microlaimidae, however, are characterised by the presence of outstretched ovaries, while Onepunema possesses reflexed ovaries, a characteristic of the Desmodoridae. This trait, in combination with the presence of a cephalic capsule in Onepunema (an important characteristic for the classification of supraspecific taxa within the Desmodorida and never found within the Microlaimoidea) suggests closer affinities with the Desmodoridae (and Desmodorinae in particular) than with the Microlaimidae. Armenteros et al. (2014: 26) incorrectly stated that " ... the presence of reflexed ovaries [...] suggest a relationship with Bolbolaimus Cobb, 1920, Calomicrolaimus Lorenzen, 1976 and Microlaimus de Man, 1880". Reflexed ovaries are not found in any of these genera; perhaps Bolbolaimus was confused with Bolbonema Cobb, 1920 (see comments under Chromaspirina longisetosa Jensen, 1985 below), which belongs to the Desmodoridae due to the presence of reflexed ovaries and a globular cephalic capsule.

Subfamily Spiriniinae Chitwood, 1936

\section{Type genus}

Spirinia Gerlach, 1963 (synonym: Spira Bastian, 1865). 
Diagnosis (from Decraemer \& Smol 2006)

Member of Desmodoridae. Body cuticle with fine annulations. Head not demarcated as a cephalic capsule. Amphideal fovea usually a simple spiral. Buccal cavity small or large, with a distinct or a minute dorsal tooth; two small ventrosublateral teeth may be present or absent.

\section{Differential diagnosis}

This subfamily is similar to the Desmodorinae but can be differentiated from the latter by the absence of a head capsule.

\section{Remarks}

The tribe Spirinacea was originally established by Chitwood (1936), before being raised to subfamily, family and superfamily rank by De Coninck (1965). According to the Principle of Coordination (ICZN, 1999, Article 36), "a name established for a taxon at any rank in the family group is deemed to have been simultaneously established for nominal taxa at all other ranks in the family group; (...). The name has the same authorship and date at every rank." The appropriate authorship for Spiriniinae should therefore be attributed to Chitwood (1936), and not Gerlach \& Murphy (1965), as is often done (e.g., Armenteros et al. 2014).

Valid genera (Cavalcanti et al. 2009; Armenteros et al. 2014)

Alaimonema Cobb, 1920

Chromaspirina Filipjev, 1918

Metachromadora Filipjev, 1918

Onyx Cobb, 1891

Papillonema Verschelde et al., 1995

Paradesmodora Schuurmans Stekhoven, 1950

Parallelocoilas Boucher, 1975

Perspiria Wieser \& Hopper, 1967

Polysigma Cobb, 1920

Pseudometachromadora Timm, 1952

Sigmophoranema Hope \& Murphy, 1972

Spirinia Gerlach, 1963

Spirodesma Cavalcanti et al., 2009

Stygodesmodora Blome, 1982

We provide emended diagnoses and updated lists of valid species for Chromaspirina, Spirinia, and Perspiria below to clarify the distinctions between them. These lists are based on the original and any subsequent descriptions; as many of the original descriptions (especially early ones) lack type material, we often had to rely on short descriptions and/or illustrations.

\section{Genus Chromaspirina Filipjev, 1918}

\section{Type species}

Chromaspirina pontica Filipjev, 1918.

Emended diagnosis (modified from Maria et al. 2009 and Muthumbi et al. 1995)

Robust body with rounded or rectangular head region and short conical tail; fine body annulations. Annulated or non-annulated head region; body annulations envelop the amphideal fovea partly, entirely, or only begin at posterior edge of amphids. Amphideal fovea uni-, crypto- or multispiral, or loopshaped. Cephalic setae at anterior edge or further posteriorly alongside amphids. Distinct buccal cavity, 
conspicuously cuticularised; large dorsal tooth and smaller subventral teeth; ventral field of denticles may be present. Pharynx with round or oval posterior bulb, sometimes weakly developed, and without cuticularised lumen. Precloacal supplements may be present.

\section{Valid species}

C. chabaudi Boucher, 1975. Main diagnostic characters: “... a medium-sized dorsal tooth and two small subventral teeth. Anterior portion with twelve chelorhabdia." Drawings show a distinct cuticularised dorsal tooth and subventral teeth (Boucher 1975: fig. 2).

C. crinita Gerlach, 1952. Main diagnostic character: "The dorsal tooth is massive and extraordinarily strong."

C. cylindricollis (Cobb, 1920). Main diagnostic characters: Only an 'onchium' is mentioned, without further comment, but a distinct cuticularised dorsal tooth is visible on the drawing (Cobb 1920: 325).

C. dubia Inglis, 1968. Drawing shows a very large dorsal tooth (Inglis 1968: fig. 53).

C. gerlachi Blome, 1982. Drawing shows a distinctly cuticularised dorsal tooth and subventral teeth (Blome 1982: fig. 20).

C. indica Gerlach, 1963. Drawing shows a very large dorsal tooth and thickly cuticularised subventral teeth (Gerlach 1963: fig. 1).

C. inglisi Warwick, 1970. Main diagnostic character: “... a prominent heavily cuticularized dorsal tooth..."; also clear in drawing (Warwick 1970: fig. 12).

C. lunatica Gerlach, 1965. Main diagnostic character: “...a strong dorsal tooth ...”; also clear in drawing (Gerlach 1965: fig. 13).

C. madagascarensis Gerlach, 1953. Main diagnostic characters: “...a rather large dorsal tooth ..."; drawing shows a large and thick dorsal tooth and subventral teeth (Gerlach 1953: fig. 4).

C. modesta Bussau, 1993. Drawing shows a large, heavily cuticularised dorsal tooth and subventral teeth (Bussau 1993: figs 55-57).

C. multipapillata Jayasree \& Warwick, 1977. Main diagnostic characters: "Buccal cavity bearing a dorsal tooth and two small subventral teeth"; drawing unclear. It is difficult to draw a firm conclusion from the description and hence this species is left in this genus.

C. parapontica Luc \& De Coninck, 1959. Main diagnostic characters: "Large dorsal tooth..."; drawing shows a large dagger-like dorsal tooth (Luc \& De Coninck 1959: fig. 35).

C. pellita Gerlach, 1954 (synonym: C. renaudae Boucher, 1975). Drawing shows a very large dorsal tooth and conspicuous subventral teeth (Gerlach 1954: fig. 4).

C. pontica Filipjev, 1918. Main diagnostic character: "Three teeth...: one large dorsal ..., and two small subventrals."

C. thieryi De Coninck, 1943. Main diagnostic character: “...with strong dorsal tooth... ”; also clear in drawing (De Coninck 1943: fig. 5). 
C. vanreuselae Verschelde \& Vincx, 1996. Main diagnostic characters: “...with huge dorsal tooth and smaller single ventral tooth"; also clear in drawing (Verschelde \& Vincx 1996: fig. 1).

\section{Species inquirendae}

C. amabilis (De Man, 1922). Considered species inquirenda by Jensen (1978).

C. cobbi Chitwood, 1938. Considered species inquirenda by Jensen (1978).

C. robusta Wieser, 1954. Considered species inquirenda by Wieser \& Hopper (1967).

\section{Remarks}

Chromaspirina cylindricollis (Cobb, 1920) (synonym: Mesodorus cylindricollis Cobb, 1920). This species was in our opinion rightly transferred to Chromaspirina as it was described with an annulated head region. Maria et al. (2009), however, mistakenly showed a drawing of the head capsule of Pseudochromadora quadripapillata Daday, 1899 (synonym: Micromicron cephalatum Cobb, 1920), in their key to Chromaspirina species, instead of the non-annulated head region of $C$. cylindricollis (Maria et al. 2009: fig. 26).

Chromaspirina denticulata (Gerlach, 1953). This species was originally described as Bolbolaimus denticulatus. Luc \& De Coninck (1959) later synonymized Bolbolaimus with Chromaspirina. However, Jensen (1978) rightly re-established the genus and re-instated Bolbolaimus denticulatus Gerlach, 1953 as a valid combination. However, he gave the wrong species authority in his identification key (Cobb, 1920 instead of Gerlach, 1953). Maria et al. (2009) included C. denticula (Gerlach, 1953) (erratum?) in their list of invalid Chromaspirina species. In conclusion, we recognize the re-establishment of Bolbolaimus denticulatus Gerlach, 1953 as a valid combination (as suggested by Jensen 1978) with the synonyms Chromaspirina denticulata (Gerlach, 1953), Bolbolaimus denticulatus Cobb, 1920 syn. nov., and Chromaspirina denticula (Gerlach, 1953) syn. nov.

Chromaspirina dimorpha (Hopper, 1961) and C. inflexa (Wieser, 1954) were rightly transferred back to Desmodora by Wieser \& Hopper (1967).

Chromaspirina longisetosa Jensen, 1985. This species was transferred to Bolbolaimus (erratum?) by Muthumbi et al. (1995), but later transferred to Bolbonema by Verschelde et al. (1998). Because this species clearly has a head capsule and cephalic setae located posterior to the amphids, we confirm that it belongs to Bolbonema. Thus, we propose the combination Bolbonema longisetosum (Jensen, 1985) with the synonyms Chromaspirina longisetosa Jensen, 1985 and Bolbolaimus longisetosus (Jensen, 1985).

Chromaspirina lunatica Gerlach, 1965 (synonym: C. lunata Gerlach, 1965 syn. nov.). Gerlach (1965) described C. lunatica, but the species is incorrectly labelled as $C$. lunata in a figure caption (p. 132).

Chromaspirina pellucida (Cobb, 1920) and C. punctata (Cobb, 1920) were rightly transferred back to Bolbolaimus by Jensen (1978).

Chromaspirina rabosa (Gerlach, 1956). This species was originally described as Desmodora rabosa and later transferred to Chromaspirina by the same author (Gerlach 1963). Muthumbi et al. (1995) argued that the species should be left in the genus Desmodora because it has "... a well-developed head capsule with the amphids situated outside the rings." We note, however, that the cephalic setae are situated posterior to the amphids, and this species is therefore transferred to the genus Bolbonema. Thus, we propose the combination Bolbonema rabosum (Gerlach, 1956) comb. nov. with the synonyms Desmodora rabosa Gerlach, 1956 and Chromaspirina rabosa (Gerlach, 1956). 
Chromaspirina spinulosa (Wieser, 1959). This species was transferred to Metadesmodora by Gerlach (1963) and then to Echinodesmodora by Blome (1982). Thus, we propose the combination Echinodesmodora spinulosa (Wieser, 1959) with the synonyms Chromaspirina spinulosa (Wieser, 1959) and Metadesmodora spinulosa (Wieser, 1959).

Genus Perspiria Wieser \& Hopper, 1967

\section{Type species}

Perspiria hamata Wieser \& Hopper, 1967.

Emended diagnosis (modified from Vincx \& Gourbault 1989)

As for Spirinia (see below), but amphids almost never completely surrounded by body annulations (seldom more than half of amphids surrounded by body annulations), amphids are entirely surrounded by annuli in some rare cases; tail conico-cylindrical to filiform. Precloacal supplements usually present.

\section{Valid species}

P. elongata (Castro et al., 2006) comb. nov. (synonym: Spirinia elongata Castro et al., 2006). Main diagnostic characters: “...one very small subventral tooth and two small dorsal teeth." The drawings show amphids completely surrounded by body annulations, but the authors describe a conico-cylindrical tail with annuli which are more evident in the tail region compared to those along the rest of the body; thus, we transfer this species to Perspiria (Castro et al. 2006: figs 3c, 4).

P. flagellata Vitiello, 1971. Main diagnostic characters: "Amphid situated anterior to cuticle striations or partially surrounded by them"; very long and slender, almost filiform tail (Vitiello 1971: fig. 29).

P. hamata Wieser \& Hopper, 1967. Drawing shows amphids only partially located within the body annuli; long and slender, almost filiform tail (Wieser \& Hopper 1967: fig. 18).

P. lara (Silva et al., 2009) comb. nov. (synonym: Spirinia lara Silva et al., 2009). Main diagnostic characters: "Buccal cavity with one dorsal tooth and two minute ventrosublateral teeth" and "Cuticle with transverse striae..., less obvious in head region than in tail." Drawing shows amphid with annulations to mid-level of amphid only, and tail is described as conico-cylindrical. This species is therefore transferred to Perspiria (Silva et al. 2009: figs 2-3).

P. megamphida Vincx \& Gourbault, 1989. Drawing shows substantial portion of the amphids is located on the non-annulated lip region; conico-cylindrical tail with more prominent annuli (Vincx \& Gourbault 1989: fig. 1).

P. mokii Coles, 1987. Main diagnostic character: “...cuticle appears smooth...”, hence amphids are not surrounded by annuli; long and slender filiform tail (Coles 1987: fig. 5).

P. papillata Vincx \& Gourbault, 1989. Drawing shows anterior half of amphids on non-annulated lip region and posterior half located within the annulated head region; long, conico-cylindrical tail (Vincx \& Gourbault 1989: fig. 2).

P. septentrionalis (Cobb, 1914) comb. nov. (synonyms: Spirinia septentrionalis (Cobb, 1914) and Spira septentrionalis Cobb, 1914). Main diagnostic characters: "From the anus the tail tapers for two-thirds of its length, then becomes cylindroid to the swollen terminus..." Drawings by Wieser (1954: fig. 126) clearly show the amphids in the head region with only their posterior half within the body annulations, 
leaving the anterior half on the non-annulated head region. The tail is conico-cylindrical. Thus, this species is transferred to the genus Perspiria.

P. striaticaudata (Timm, 1962). Tail long (11-17 abd) and slender with distinct annuli; thus it is transferred to Perspiria. Synonym: Spirina striaticaudata Timm, 1962.

\section{Species inquirenda}

Perspiria sabulicola (Filipjev, 1918/1921) comb. nov. (synonym: Spirina sabulicola Filipjev, 1918/ 1921). This species was described with a 'long tail (length $4 \times$ width)' and hence should be transferred to the genus Perspiria. However, as the species was described based on only one female, it is regarded as a species inquirenda.

Genus Spirinia Gerlach, 1963

\section{Type species}

Spira parasitifera Bastian, 1865.

\section{Emended diagnosis}

Robust body with rounded or conical head region and conical tail, fine body annulations. Annulated head region; body annulations normally completely surround the amphideal fovea, with few exceptions. Spiral amphideal fovea. Buccal cavity narrow, lightly cuticularised; no or small/inconspicuous dorsal tooth, no or minute subventral teeth. Pharynx with small pyriform, oval, or rounded posterior bulb without cuticularised lumen. Precloacal supplements usually absent. Short conical tail.

\section{Valid species}

Spirinia gerlachi (Luc \& De Coninck, 1959). Main diagnostic characters: "Annulations beginning halfway down the lateral organ... long attenuated conical tail"; also clear in drawings (Luc \& De Coninck 1959: fig. 25). Despite the presence of an amphid only partially surrounded by cuticle annulations, this species is left within Spirinia because of the shape of the tail (conical), which is the primary trait for differentiating between Spirinia and Perspiria.

Spirinia gnaigeri Ott, 1977. Amphids almost entirely located within the body annulations in one male, but only the posterior half of another male's amphid is surrounded by body annulations (compare figs 42 and 43 in Ott 1977); however, as the species has a conical tail, it belongs within Spirinia.

S. guanabarensis (Maria et al., 2009) comb. nov. (synonym: Chromaspirina guanabarensis Maria et al., 2009). Main diagnostic characters: "Buccal cavity large with an acute dorsal tooth and two smaller ventrosublateral teeth." However, later in the text it is stated that: "Chromaspirina guanabarensis sp. nov. belongs to the group of species characterized by a poorly developed dorsal tooth." Drawings also show a small buccal cavity with a small dorsal tooth and minute subventral teeth (Maria et al. 2009: fig. 1). Tail is conical. This species is therefore transferred to Spirinia.

S. hopperi Coles, 1987. Main diagnostic characters: "Cuticle without striations... small dorsal tooth is present in the narrow mouth cavity." Drawings show a conical tail (Coles 1987: fig. 3).

S. inaurita (Wieser \& Hopper, 1967) comb. nov. (synonym: Chromaspirina inaurita Wieser \& Hopper, 1967). Main diagnostic characters: "Buccal cavity with three small teeth (these teeth are smaller than in most other species of Chromaspirina and stress the proximity of the genus to Spirinia)."; the drawings are inconclusive, but the description clearly describes small teeth. This species is therefore transferred to Spirinia. 
S. laevioides Gerlach, 1963. The drawing shows a small buccal cavity, a small dorsal tooth, and amphids located within the annulated head region (Gerlach 1963: fig. 2).

S. laevis (Bastian, 1865) (synonym: S. pilosa Allgén, 1935). The drawing shows small teeth, amphids located entirely within the annulated head region, and a short conical tail (Bastian 1865: fig. 204).

S. okemwai (Muthumbi et al., 1995) comb. nov. (synonym: Chromaspirina okemwai Muthumbi et al., 1995). We studied the type material, which shows that this species has a cylindrical pharynx with only a slightly swollen terminal bulb, whose shape cannot be described. The teeth are difficult to distinguish and hence cannot be called 'large' or 'distinct'; therefore, we transfer this species to the genus Spirinia.

S. parasitifera (Bastian, 1865). Some descriptions of this species show the amphids being only partially surrounded by annulations (Gerlach 1963; Vincx \& Gourbault 1989), and others describe specimens with amphids entirely surrounded by annulations (Coles 1987; Vincx \& Gourbault 1989); furthermore, additional descriptions and drawings depict either a conical tail (Gerlach 1963: fig. 1; Coles 1987: fig. 3) or a prolonged conical to long conical tail (Wieser \& Hopper 1967: fig. 17). Hence, until further examination and comparison of these different specimens can be done, we leave this species within Spirinia.

S. parma (Ott, 1972) comb. nov. (synonym: Chromaspirina parma Ott, 1972). Main diagnostic characters: “... stoma conical, with a small acute dorsal tooth and two minute ventral teeth..."; this species is therefore transferred to the genus Spirinia.

S. schneideri (Villot, 1875). Luc \& Deconinck (1959) describe this species with a smooth cuticle, and Coles (1987) describes it "without cuticular striations". The SEM micrograph by Coles (1987: fig. 9a), however, shows striations surrounding the amphids. The tail is short and conical.

S. sophia Silva et al., 2009. Main diagnostic characters: "Buccal cavity with one dorsal tooth and two minute, ventrosublateral teeth"; clear in drawings, which also show the amphid completely surrounded by cuticle annulations (Silva et al. 2009: fig. 6). Tail conical.

\section{Species inquirendae}

Spirinia granulata (Allgén, 1929) comb. nov. (synonym: Spirina granulata Allgén, 1929). This species was described based on two juveniles only, with very poor drawings and inadequate descriptions. Hence, we have to regard this species as species inquirenda.

S. paucispira (Schuurmans Stekhoven, 1950) comb. nov. (synonym: Chromaspirina paucispira Schuurmans Stekhoven, 1950). This species was considered species inquirenda by Wieser \& Hopper (1967) and Muthumbi et al. (1995), because the original description was based on a single female specimen. It was stated that the buccal cavity of this species has an "indication of a dorsal tooth". Based on this character, which is sufficient to distinguish between Spirinia and Chromaspirina, this species is transferred to the genus Spirinia (but remains species inquirenda due to the incomplete nature of the original description).

S. similis (Cobb, 1898) (synonym: Spira similis Cobb, 1898). Considered invalid by Coles (1987) due to lack of illustrations.

S. tenuicauda (Allgén, 1959) (synonym: Spirina tenuicauda Allgén, 1959). This species has to be regarded as a species inquirenda, as the only description Allgén made was to write "differing from $S p$. parasitifera," and his drawings are inadequate. 


\section{Spirinia verecunda sp. nov. urn:1sid:zoobank.org:act:83F4CF38-29CF-4540-B05D-2245120A489B}

Figs 1-3; Table 1

\section{Diagnosis}

Spirinia verecunda sp. nov. is characterised by a short, stout body, cuticle covered in minute hair-like structures, unispiral amphideal aperture and cryptospiral amphideal fovea, buccal cavity with a small dorsal tooth and minute subventral teeth, eight elongated glands surrounding the anterior portion of the pharynx, large sperm cells, spicules with weak capitulum, and absence of precloacal supplements.

\section{Type material}

Holotype

NEW ZEALAND: $\widehat{\jmath}$, NIWA 88379, 20 Feb. 2011, NIWA cruise TAN1103, station 69, central Chatham Rise, $43.331^{\circ} \mathrm{S}, 178.288^{\circ} \mathrm{E}, 350 \mathrm{~m}$.

\section{Paratypes}

NEW ZEALAND: 2 우, NIWA 88380, same data as holotype.

\section{Etymology}

The species name is derived from the Latin word verecundus (bashful, shy, coy), in reference to the anterior part of the head region deeply folded inwards.

\section{Description}

\section{Male}

Body stout, cylindrical, pale orange colour, tapering slightly towards both ends. Annulated cuticle, no lateral differentiation; annulations $0.6-0.8 \mu \mathrm{m}$ apart; cuticle slightly thicker in pharyngeal region than elsewhere (2.2-2.5 vs 1.6-2.0 $\mu \mathrm{m})$. Cuticle covered with dense layer of minute hair-like structures from posterior to amphid to near tail tip (barely visible under light microscope; Fig. 3A-B); larger, $1 \times 5 \mu \mathrm{m}$ bacteria-like structures with narrow base also attached in pharyngeal region (Fig. 1D). A single protist, $74 \mu \mathrm{m}$ long and $18 \mu \mathrm{m}$ wide attached subdorsally near cloaca (Fig. 3E). Short somatic setae arranged in eight longitudinal rows along entire body length.

Blunt, slightly rounded annulated head region with annulations completely surrounding amphid (Fig. 1A-B). Four cephalic setae near anterior edge of amphid; inner and outer labial sensillae not observed because labial region is folded inwards from level of cephalic setae. Cryptospiral amphideal fovea with slightly cuticularised outline and unispiral amphideal aperture (Fig. 3A-B).

Buccal cavity with slightly cuticularised dorsal tooth and minute subventral teeth. Eight elongated glands, 12-17 $\mu \mathrm{m}$ in length, distributed around anterior portion of pharynx just posterior to buccal cavity (Figs 1C-D, 3C). Pharynx muscular, oval-shaped posterior pharyngeal bulb, lumen not cuticularised. Nerve ring at $40-50 \%$ of pharynx length. Secretory-excretory system not observed. Cardia 10-12 $\mu \mathrm{m}$ long.

Reproductive system monorchic, with relatively large, outstretched testis situated to the left of intestine. Mature sperm large, globular to elongated in shape, up to $16 \mu \mathrm{m}$ in length. Short, arcuate spicules with weak capitulum and tapering distally; velum present (Fig. 1G). Gubernaculum with cuneus broadest in middle portion and tapering proximally and distally; poorly developed lateral crurae (Fig. 1H). Precloacal supplements not observed. Tail conical, with two pairs of short subventral setae and one pair of subdorsal setae; three caudal glands restricted to tail region and spinneret present. 
A

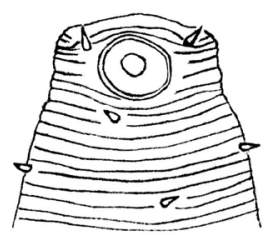

B

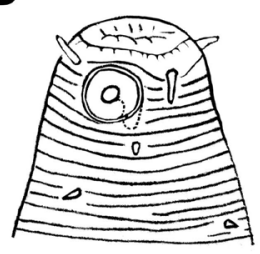

C
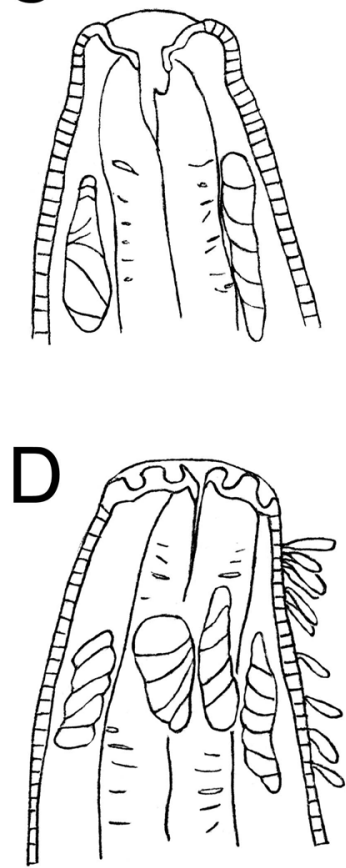

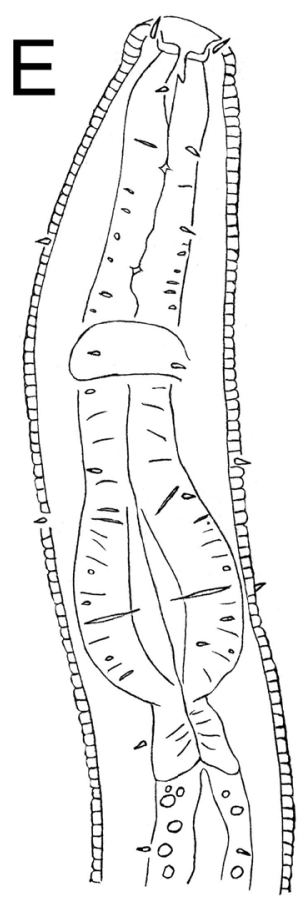

$\mathrm{F}$

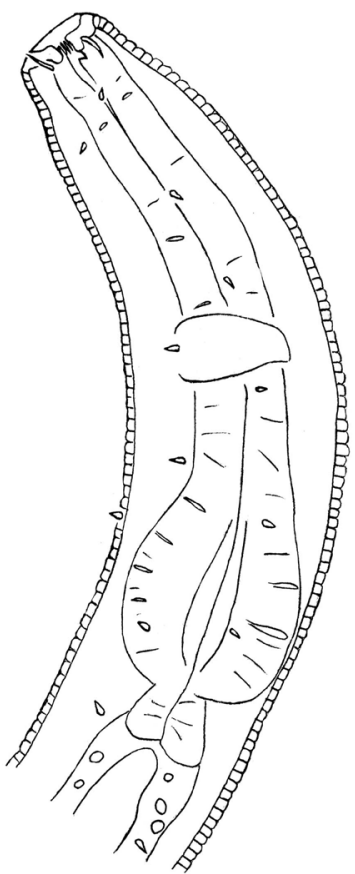

$J$

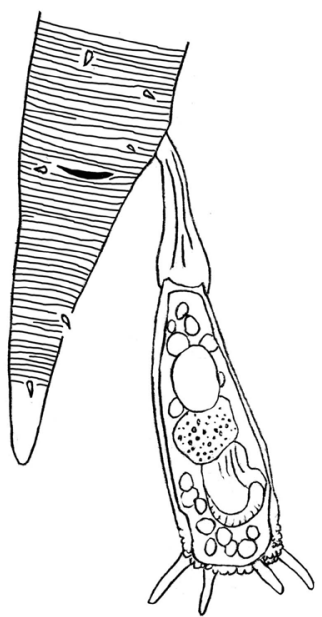

Fig. 1. Spirinia verecunda sp. nov. A. Surface view of male head. B-C. Male head, showing buccal cavity. D. Female head, showing bacteria attached to cuticle. E. Anterior body region of male. F. Anterior body region of female. G. Posterior body region of male. H. Gubernaculum, with details of crurae (left) and cuneus (right). I. Posterior body region of female. J. Posterior body region of female, showing attached protist. Scale bar: A-D, $\mathrm{I}=20 \mu \mathrm{m}, \mathrm{E}-\mathrm{F}=30 \mu \mathrm{m}, \mathrm{G}=16 \mu \mathrm{m}, \mathrm{H}=12 \mu \mathrm{m}, \mathrm{J}=35 \mu \mathrm{m}$. 


\section{Female}

Similar to male, but with wider body. One specimen bears a single protist (suctorian) on tail. Reproductive system didelphic, amphidelphic with reflected ovaries situated either both on the right or both on the left of intestine. Vulva located slightly post median. Cuticular pars distalis vaginae and pars proximalis vaginae surrounded by constrictor muscle.

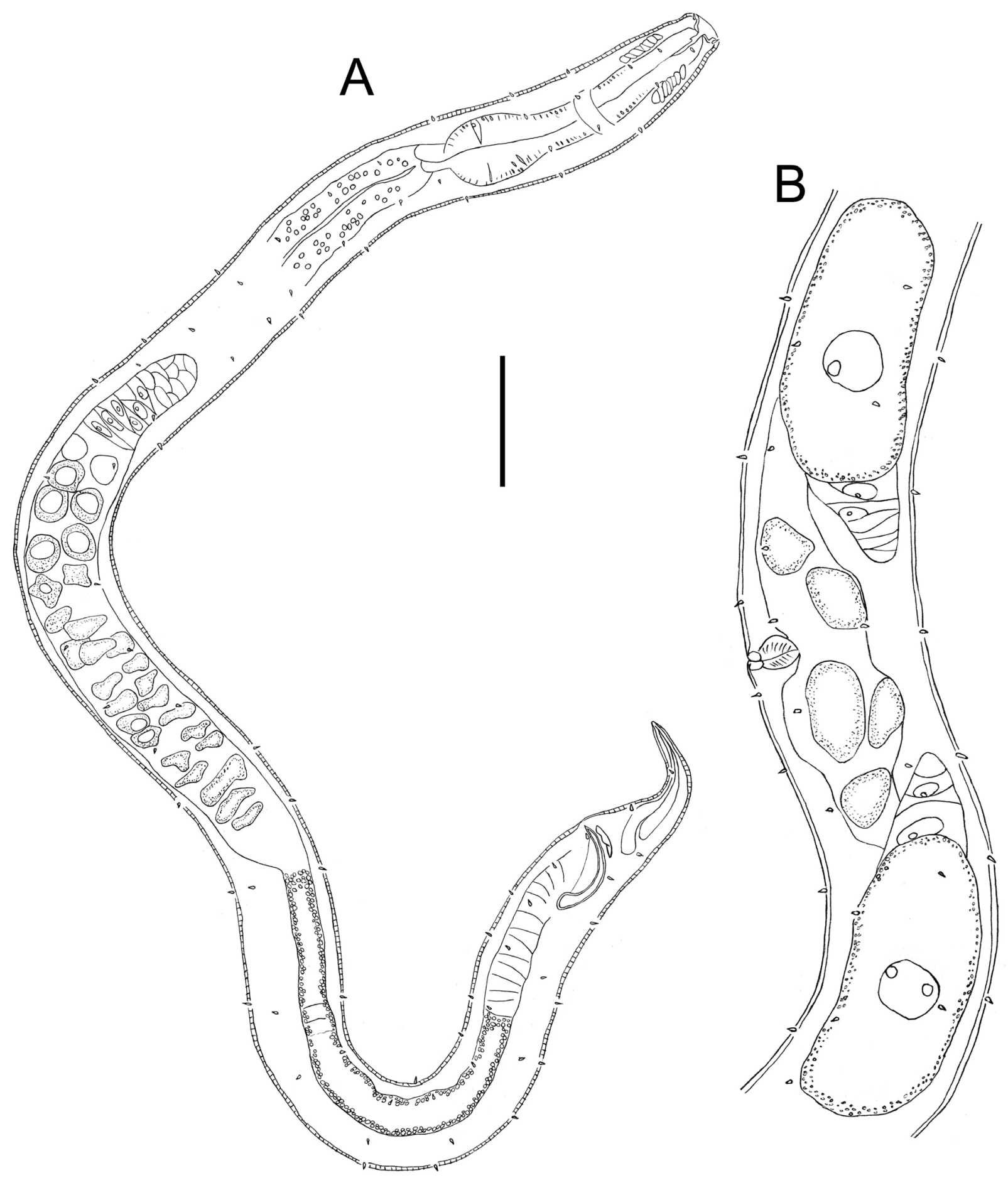

Fig. 2. Spirinia verecunda sp. nov. A. Entire male. B. Female reproductive system. Scale bar: A = 50 $\mu \mathrm{m}, \mathrm{B}=30 \mu \mathrm{m}$. 

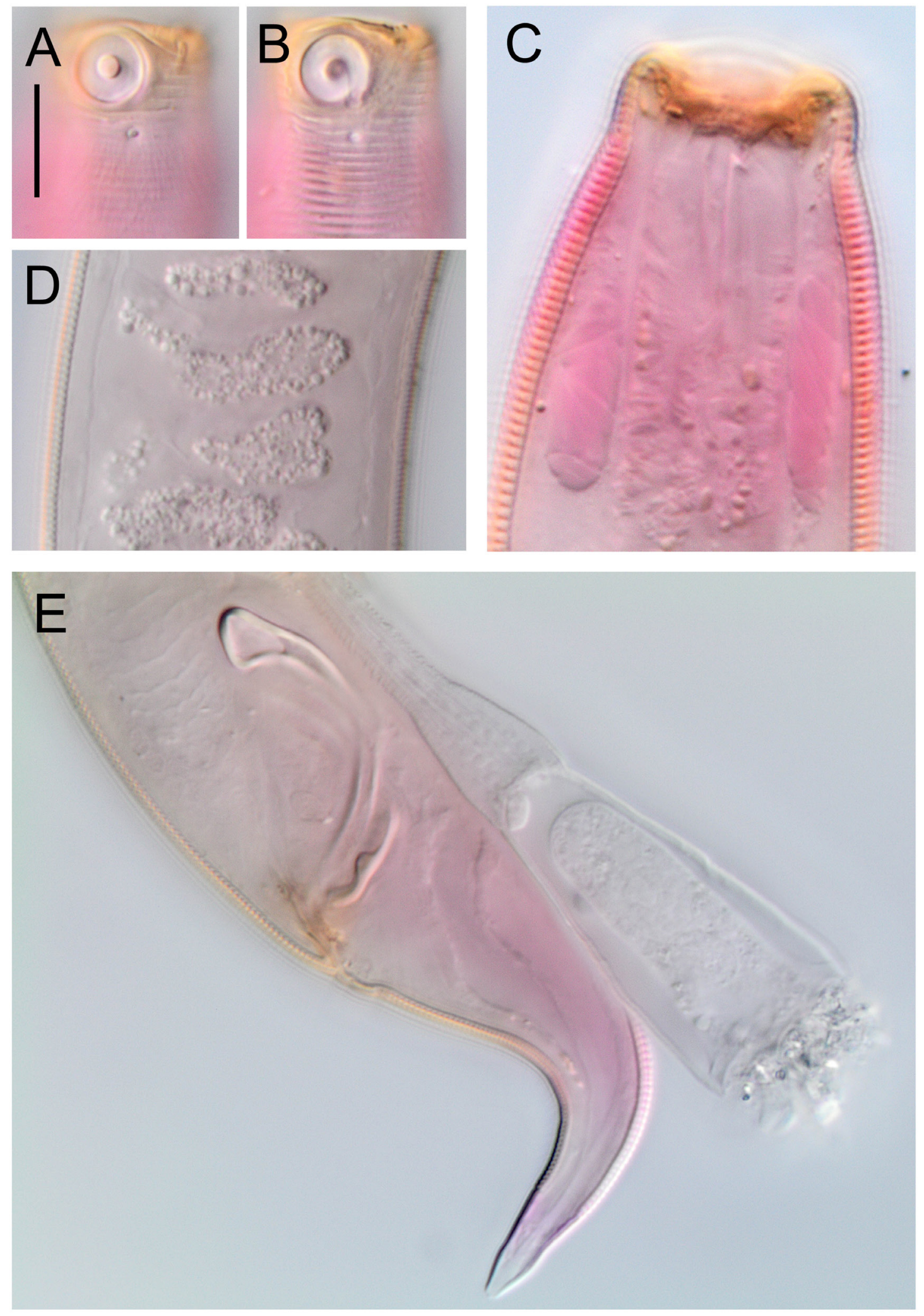

Fig. 3. Spirinia verecunda sp. nov., light micrographs. A. Male head, showing amphideal aperture and and cuticular hair-like structures. B. Male head, showing amphideal fovea. C. Male anterior body region showing buccal cavity and elongated glands. D. Mature sperm cells. E. Posterior body region of male, showing copulatory apparatus and attached protist. Scale bar: A-B, D-E $=10 \mu \mathrm{m}, \mathrm{C}=8 \mu \mathrm{m}$. 
Table 1. Morphometrics $(\mu \mathrm{m})$ of Spirinia verecunda sp. nov. and Stygodesmodora confusa sp. nov. — a, body length/maximum body diameter; abd, anal body diameter; $b$, body length/pharynx length; c, body length/tail length; cbd, corresponding body diameter; V, vulva distance from anterior end of body; $\% \mathrm{~V}, \mathrm{~V} /$ total body length.

\begin{tabular}{|c|c|c|c|c|c|}
\hline & \multicolumn{2}{|c|}{ Spirinia verecunda sp. nov. } & \multicolumn{3}{|c|}{ Stygodesmodora confusa sp. nov. } \\
\hline & $\hat{0}$ & 우 & ठ & & 우 \\
\hline & Holotype & Paratypes & Holotype & Paratype & Paratypes \\
\hline $\mathrm{n}$ & - & 2 & - & 1 & 5 \\
\hline $\mathrm{L}$ & 757 & 667,675 & 1241 & 795 & $778-1029$ \\
\hline $\mathrm{a}$ & 22 & 17 & 35 & 28 & $22-34$ \\
\hline $\mathrm{b}$ & 8 & 6,7 & 11 & 8 & $8-10$ \\
\hline $\mathrm{c}$ & 15 & 13 & 13 & 14 & $12-15$ \\
\hline Head diameter & 17 & 17,18 & 18 & 14 & $14-16$ \\
\hline Length of cephalic setae & 2 & 2 & $7-8$ & $6-9$ & $5-9$ \\
\hline Amphid height & 6 & 6,7 & 11 & 6 & $5-6$ \\
\hline Amphid width & 6 & 6,7 & 11 & 6 & $6-7$ \\
\hline Amphid width/cbd (\%) & 35 & 33,41 & 61 & 43 & $40-47$ \\
\hline Amphid from anterior end & 2 & 3 & 4 & 5 & $3-7$ \\
\hline Nerve ring from ant. end & 49 & 45,53 & 68 & 59 & $57-62$ \\
\hline Nerve ring cbd & 32 & 32,33 & 29 & 25 & $24-25$ \\
\hline Pharynx length & 100 & 100,107 & 109 & 95 & $92-105$ \\
\hline Pharyngeal bulb diameter & 26 & 27 & 22 & 20 & $20-22$ \\
\hline Pharyngeal bulb cbd & 31 & 33,34 & 29 & 25 & $25-28$ \\
\hline Max. body diameter & 35 & 39,40 & 35 & 42 & $30-37$ \\
\hline Spicule length & 38 & - & 39 & 42 & - \\
\hline Gubernaculum length & 13 & - & 10 & 12 & - \\
\hline Anal body diameter & 24 & 21,22 & 28 & 21 & $17-20$ \\
\hline Tail length & 49 & 51,52 & 93 & 57 & $62-85$ \\
\hline Tail length/abd & 2.0 & 2.4 & 3.3 & 2.7 & $3.5-4.5$ \\
\hline $\mathrm{V}$ & - & 347,361 & - & - & $428-558$ \\
\hline$\% \mathrm{~V}$ & - & 51,54 & - & - & $53-55$ \\
\hline Vulval body diameter & - & 39,40 & - & - & $30-37$ \\
\hline
\end{tabular}

\section{Remarks}

Spirinia verecunda sp. nov. shows similarities with several Spirinia and Chromaspirina species, i.e., Spirinia guanabarensis comb. nov., S. inaurita comb. nov., S. okemwai comb. nov., S. parma comb. nov., Chromaspirina chabaudi, and C. multipapillata. Of these, $S$. verecunda sp. nov. resembles S. okemwai comb. nov. the most in cuticle ornamentation (annulated head region, cuticle with minute hairlike structures), size and shape of the amphids, presence of large sperm cells, and absence of precloacal supplements. $S$. verecunda sp. nov. differs from the latter in having shorter body length (667-757 vs

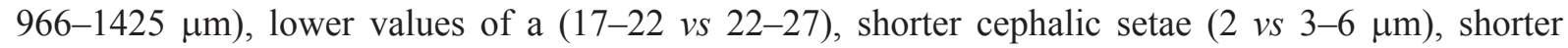
spicules (38 vs 41-50), and shorter gubernaculum (13 vs 19-25). S. verecunda sp. nov. also differs from S. okemwai comb. nov. in the presence of elongated glands in the anterior region of the pharynx (absent in S. okemwai comb. nov.) and the structure of the gubernaculum (hook absent $v$ s dorsally directed proximal hook). $S$. verecunda sp. nov. can most readily be distinguished from $S$. inaurita comb. nov. and $S$. parma comb. nov. by the size of the amphids (in males: $35 \%$ cbd in $S$. vercunda sp. nov. vs $>$ 
$60 \%$ cbd in S. inaurita comb. nov. and S. parma comb. nov.), from Chromaspirina chabaudi by the structure of the gubernaculum (not surrounding spicules in $S$. verecunda sp. nov. vs surrounding spicules distally in C. chabaudi), from C. multipapillata by the absence of precloacal supplements (present in $C$. multipapillata), and from $S$. guanabarensis comb. nov. by its small body size $(<800 \mu \mathrm{m}$ in $S$. verecunda sp. nov. vs $>1800 \mu \mathrm{m}$ in S. guanabarensis comb. nov.) and low values of a (17-22 vs 30-48).

\section{Genus Stygodesmodora Blome, 1982}

\section{Type species}

Stygodesmodora epixantha Blome, 1982.

Emended diagnosis (modified from Blome 1982)

Cuticle with coarse annulations; numerous long somatic setae may be present; annulated head region (sometimes intraspecific variation, with the head of some specimens only partially annulated in dorsal and ventral regions). Amphid unispiral or spiral located on amphideal plate; small to medium sized buccal cavity with dorsal tooth and (usually) smaller subventral teeth. Pharynx with rounded or pyriform posterior bulb, without cuticularised lumen. Pre-cloacal supplements present or absent; spicules short, arcuate, and with well-developed capitulum; gubernaculum present.

\section{Valid species}

S. bacillicauda (Gerlach, 1963)

S. epixantha Blome, 1982

\section{Species inquirenda}

S. rotundicephala (Cobb, 1920)

\section{Stygodesmodora confusa sp. nov. urn:Isid:zoobank.org:act:44B8B268-21AE-4E30-8A7E-D707B1D54C8F}

Figs 4-7; Table 1

\section{Diagnosis}

Stygodesmodora confusa sp. nov. is characterised by a relatively short body $(778-1241 \mu \mathrm{m})$, spiral amphids with 1.0-1.25 turns, cephalic setae situated at or slightly posterior to mid-level of amphid, and males with four precloacal supplements consisting of short setae on wide bases.

\section{Type specimens}

\section{Holotype}

NEW ZEALAND: ${ }^{\top}$, NIWA 88377, 24 Apr. 2010, NIWA cruise TAN1004, station 92, canyon axis on southern Hikurangi Margin, $41.8921^{\circ} \mathrm{S}, 174.6347^{\circ} \mathrm{E}, 686 \mathrm{~m}$.

\section{Paratypes}

NEW ZEALAND: 1 ภ, 2 우, NIWA 88378, 20 Feb. 2011, NIWA cruise TAN1103, station 69, central Chatham Rise, $43.331^{\circ} \mathrm{S}, 178.288^{\circ} \mathrm{E}, 350 \mathrm{~m} ; 3$ 우 (same data as other paratypes) were measured to provide morphometric data and then processed for scanning electron microscopy.

\section{Etymology}

The species name is derived from the Latin adjective confusus, meaning confused, perplexed or obscure (feminine form used, as -dora is feminine), and refers to the close affinities of this species with other desmodorid genera (see Remarks), which resulted in initial confusion in the placement of this species. 


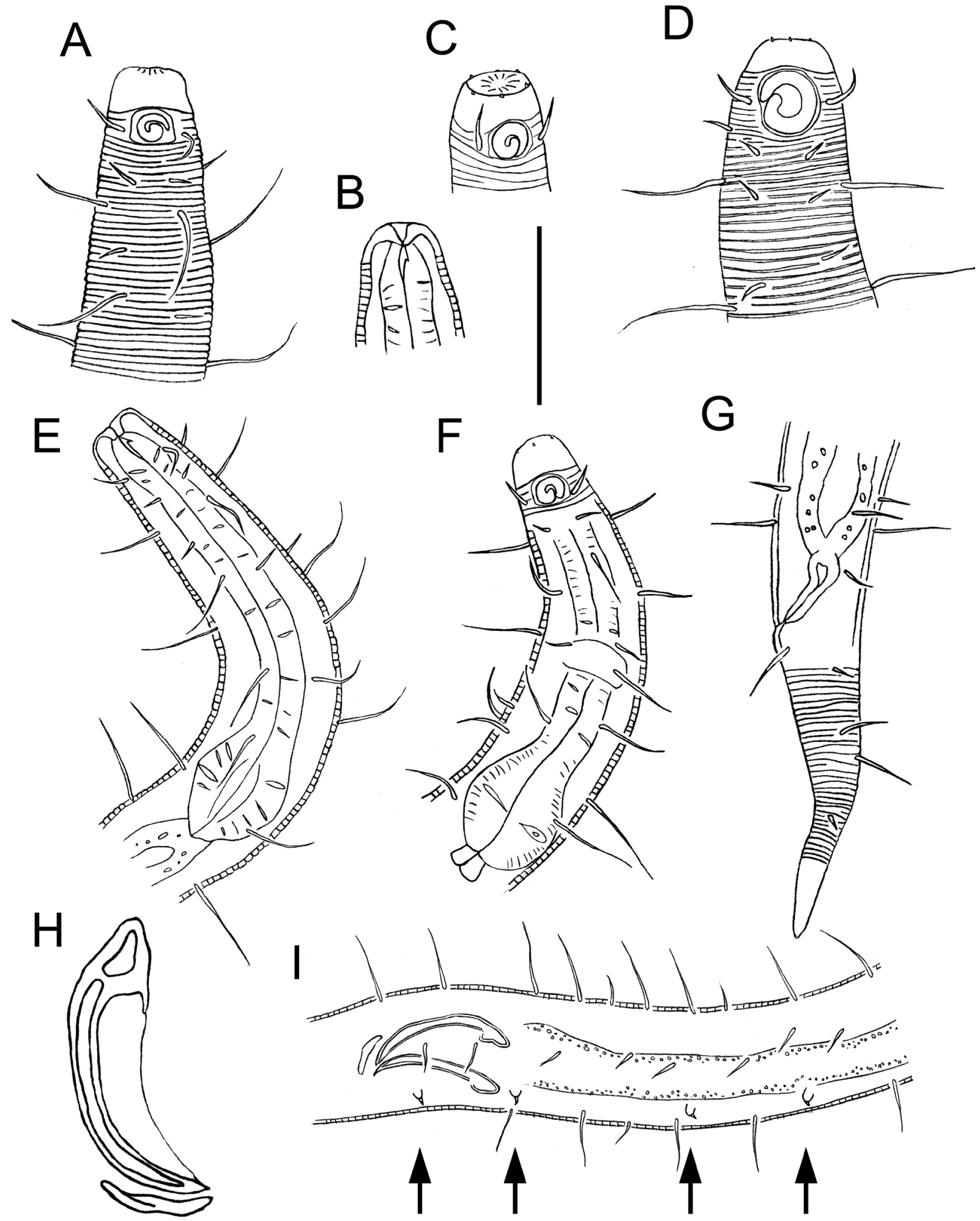

Fig. 4. Stygodesmodora confusa sp. nov. A. Anterior body region of female. B. Male head (holotype). C. Male head (paratype). D. Male head (holotype). E-F. Anterior body region of female. G. Female posterior body region. H. Right spicule and gubernaculum. I. Male copulatory apparatus. Arrows show position of pre-cloacal supplements. Scale bar: $A-D=30 \mu \mathrm{m}, \mathrm{E}-\mathrm{G}=36 \mu \mathrm{m}, \mathrm{H}=20 \mu \mathrm{m}, \mathrm{I}=40 \mu \mathrm{m}$. 


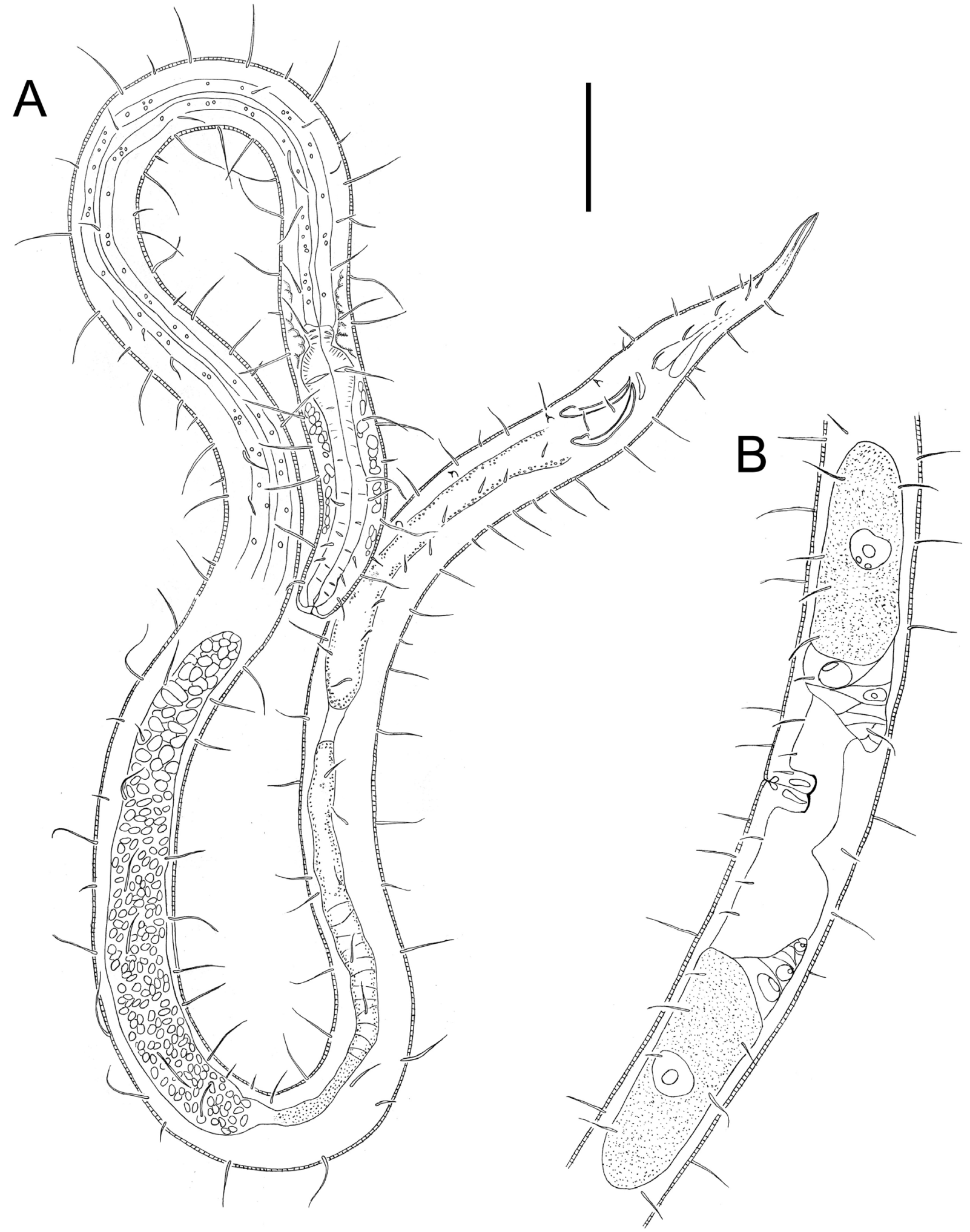

Fig. 5. Stygodesmodora confusa sp. nov. A. Entire male. B. Female reproductive system. Scale bar: $\mathrm{A}=50 \mu \mathrm{m}, \mathrm{B}=36 \mu \mathrm{m}$. 


\section{Description}

\section{Male}

Relatively short cylindrical body, pale golden colour, tapering slightly towards both ends. Cuticle $0.9-$ $1.4 \mu \mathrm{m}$ thick, with coarse annuli, approximately $1 \mu \mathrm{m}$ apart, no lateral differentiation. Ventral ala absent. Somatic setae of different sizes (4-19 $\mu \mathrm{m}$ long; Fig. 5A), set out in eight longitudinal rows in anterior one fifth of body length and in six longitudinal rows along rest of body except on tail, where they are irregularly arranged.

Annulated head region with annulations completely surrounding amphid (Figs 6A-C, 7C); in some specimens, there is a seemingly non-annulated head region, but some partial annulation of the dorsal
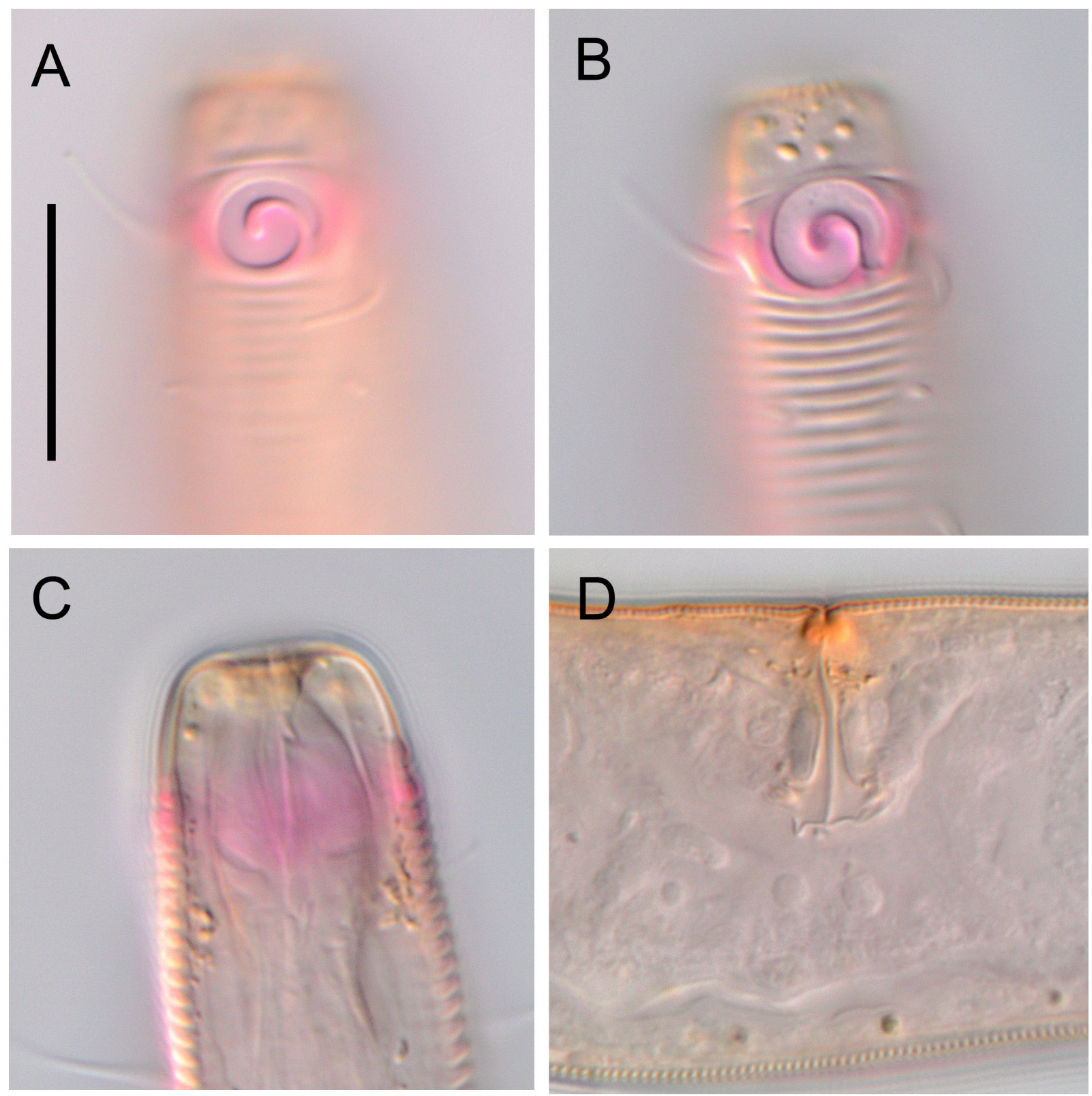

Fig. 6. Stygodesmodora confusa sp. nov., light micrographs of female. A. Head region showing amphideal aperture. B. Head region showing amphideal fovea. C. Head region showing buccal cavity. D. Vulva. Scale bar: A-C $=15 \mu \mathrm{m}, \mathrm{D}=18 \mu \mathrm{m}$. 

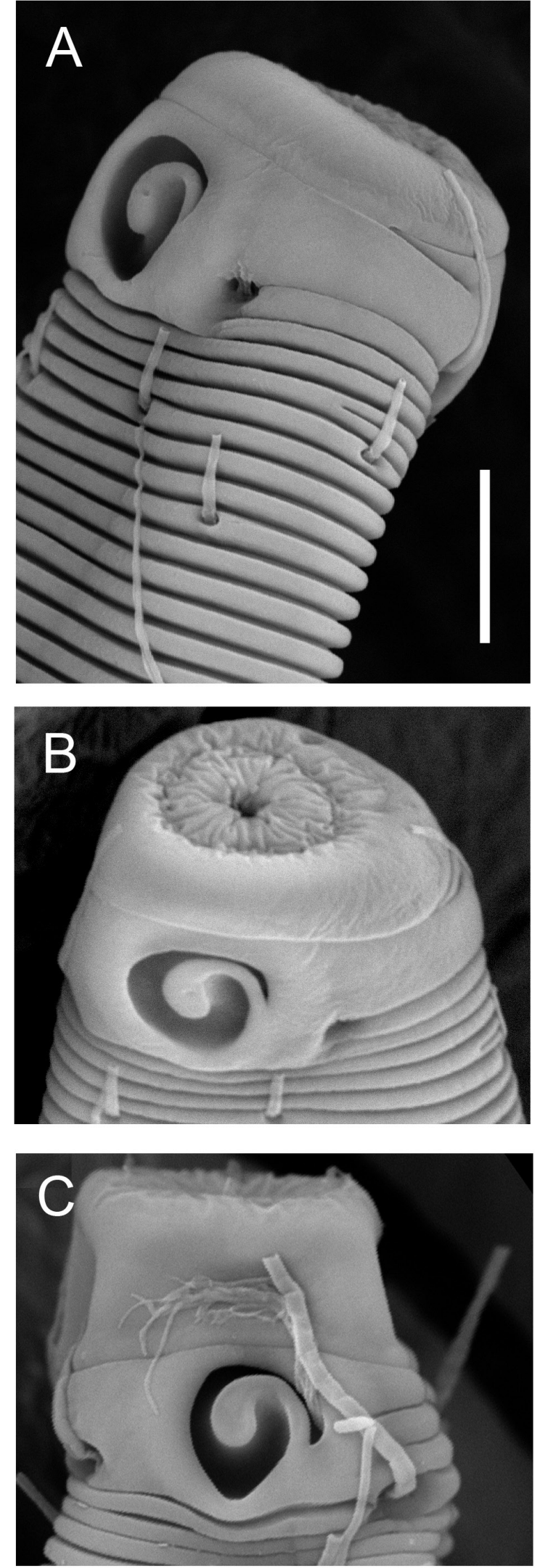

Fig. 7. Stygodesmodora confusa sp. nov. Scanning electron micrographs. Female head (three different specimens). Scale bar $=5 \mu \mathrm{m}$. 
and ventral sides of the head can be observed (Fig. 7A-B); both forms are considered annulated head regions, even though the degree of annulation differs between the two morphotypes. Labial region folded inwards in all specimens. Six papilliform outer labial sensillae and four cephalic setae, $44-57 \%$ cbd long, situated at or slightly posterior to mid-level of amphid. Spiral amphideal fovea, 1.2-1.4 turns, located on a cuticularised amphideal plate (Figs 6B, 7B), larger in holotype than in paratype ( $\sim 0.6 v s 0.4$ cbd, respectively; Fig. 4C-D); amphideal aperture with similar shape to amphideal fovea but tapering proximally (compare Fig. 6A and 6B).

Buccal cavity small, with small dorsal tooth; subventral teeth not observed (Fig. 6C). Pharynx muscular, slightly swollen at anterior extremity, and with pyriform bulb at posterior extremity. Nerve ring at 60 $62 \%$ of pharynx length. Secretory-excretory system not observed. Cardia short.

Reproductive system monorchic, with single anterior testis situated to the right of intestine, 53-63 $\mu \mathrm{m}$ long, outstretched and opposed. Mature sperm small, globular, 2-3 $\times 3-5 \mu \mathrm{m}$. Short, arcuate spicules tapering distally; well-developed capitulum and broad velum (Fig. 4H). Small, plate-shaped gubernaculum without crurae. Four pre-cloacal supplements consisting of short setae on broad bases (Fig. 4I), 23-45 $\mu \mathrm{m}$ apart, beginning $15 \mu \mathrm{m}$ anterior to cloaca. Tail conical, with three small caudal glands and spinneret.

\section{Female}

Similar to males. Female reproductive system didelphic, amphidelphic with reflected ovaries situated either to the right or left of intestine, with anterior and posterior ovaries always situated on opposite sides. Vulva located slightly post median. Cuticular pars distalis vaginae and pars proximalis vaginae surrounded by constrictor muscle. Mature eggs $66-73 \times 25 \mu \mathrm{m}$.

\section{Remarks}

Stygodesmodora confusa sp. nov. can most easily be differentiated from the other two species of the genus by the location of the cephalic setae at mid-level of amphids ( $v s$ anterior to amphids in S. bacillicauda and $S$. epixantha). S. confusa sp. nov. also differs from $S$. bacillicauda in the presence of pre-cloacal supplements (absent in S. bacillicauda) and the absence of lateral crurae on the gubernaculum (present in S. bacillicauda), and from S. epixantha by the presence of numerous long somatic setae (short somatic setae in S. epixantha).

Stygodesmodora confusa sp. nov. closely resembles species of other desmodorid genera, and distinguishing it from these other species requires careful examination of the head region. S. confusa sp. nov. resembles Echinodesmodora moensi Verschelde \& Vincx, 1996 in the absence of a cephalic capsule, numerous long somatic setae, and cephalic setae at or slightly posterior to mid-level of amphids, but can be differentiated from the latter by the absence of pharyngeal lumen cuticularisation (present in E. moensi), amphid shape ( $\leq 1.25$ turns $v s$ 1.5-2.0 turns in E. moensi), presence of setose precloacal supplements (absent in E. moensi), and the absence of knotty protrusions on the tail (present in $E$. moensi). The most important distinction, however, is the presence of an amphideal plate in $S$. confusa sp. nov. This species is also superficially similar to species of Bolbonema, i.e., B. brevicolle (Cobb, 1920), B. longisetosum (Jensen, 1985) comb. nov., and B. spiralis Hourston \& Warwick, 2010, in the presence of both short and long somatic setae, cephalic setae just posterior to mid-level of amphid, and in the structure of the copulatory apparatus. The amphideal plates in $S$. confusa sp. nov. give a swollen appearance to the head region laterally (see Fig. 7A), and in some specimens there is a gap in the body annulations in the head region (compare Fig. 7A and 7C), which may be wrongly interpreted as a nonannulated head region or even a head capsule. S. confusa sp. nov., however, is clearly defined by an annulated region, and not a head capsule, because (1) the swollen part of the head is mostly restricted 
to the area surrounding the amphids (i.e., the amphideal plates), (2) the cuticle is the same thickness in head and body regions (see Fig. 6C), and (3) annulations are present dorsally and ventrally at least to mid-level of amphids, with one continuous annulation anterior to the amphid (see Figs 6B, 7A-C). The genus Bolbonema, however, is characterized by a globular head capsule (i.e., conspicuously thicker cuticle and absence of annulations; Verschelde \& Vincx 1996; Verschelde et al. 1998).

\section{Discussion}

Muthumbi et al. (1995) provided an emended diagnosis for Chromaspirina and, more recently, Silva et al. (2009) provided an emended diagnosis for Spirinia. Maria et al. (2009) briefly discussed the relationship between Chromaspirina and Spirinia. They identified the size of the buccal cavity and dorsal tooth, and the shape of the posterior pharyngeal bulb as the main distinguishing features between the two genera and noted that several Chromaspirina species have a small dorsal tooth which "emphasises the close relationship of this genus with Spirinia..." and that "further investigation is needed into the relationships [of] Spirinia with Chromaspirina" (Maria et al. 2009: 28). In his review of Spirinia, Coles (1987) identified buccal morphology as the main distinguishing feature between the two genera.

We argue that the shape of posterior pharyngeal bulb and the presence or absence of precloacal supplements show too much overlap to be useful diagnostic features to distinguish Spirinia and Chromaspirina. For example, S. okemwai comb. nov. and S. guanabarensis comb. nov. lack precloacal supplements (a trait usually associated with Spirinia), but possess relatively weakly developed, ovalshaped posterior pharyngeal bulbs (a trait usually associated with Chromaspirina; see Maria et al. 2009). S. sophia Silva et al., 2009 also appears to be intermediate between the two genera: it possesses precloacal supplements (absent in all other Spirinia species but present in some Chromaspirina species) and a round to oval-shaped posterior pharyngeal bulb (despite Spirinia being defined as having a round posterior pharyngeal bulb; see Silva et al. 2009). Differences in the morphology of the pharyngeal bulb and precloacal supplements are not reliable traits to distinguish between Chromaspirina and Spirinia because (1) differences in the shape of pharyngeal bulbs are often subtle (e.g., pyriform vs elongated or oval) and (2) precloacal supplements in these two genera are often difficult to distinguish and may have been omitted in some species descriptions. Buccal morphology provides the clearest and most consistent way to differentiate between Spirinia and Chromaspirina because it can easily be observed; morphological features of the head region are also the most important traits for differentiating between desmodorid genera.

Perspiria was originally described as a subgenus of Spirinia by Wieser \& Hopper (1967). The only distinguishing feature of this subgenus given by the latter authors was "the more prominently striated and flagellate tail." Coles (1987) also gave the same distinguishing features between the two subgenera. Vincx \& Gourbault (1989) later raised Perspiria to generic status and included two key characteristics in their diagnosis of the genus: amphids only partially surrounded by cuticle annulations and a "prominently striated" and "filiform" tail, which we interpret as a coarsely annulated, conico-cylindrical tail from the drawings (see figs 1 and 2 in Vincx \& Gourbault 1989). Some Spirinia species, however, have coarsely annulated (e.g., S. verecunda sp. nov.) or conico-cylindrical tails (e.g., S. septentrionalis (Cobb, 1914)), and others have amphids not completely surrounded by the body annulations (e.g., S. lara Silva et al., 2009). Here, we propose to differentiate between Spirinia and Perspiria primarily based on tail shape (conical vs conico-cylindrical to filiform), as well as position of amphids relative to cuticle annulations (entirely vs partially surrounded), and have suggested nomenclatural changes to reflect these distinctions.

The monospecific genus Spirodesma was recently described by Cavalcanti et al. (2009) from continental slope sediments in the Southwest Atlantic. The authors argued that the genus is most similar to Chromaspirina based on the rounded shape of the head, annulated cuticle, spiral amphideal fovea, and 
conical tail. We consider these arguments invalid because (1) an annlated cuticle is also a characteristic of some Spirinia (e.g., Spirinia verecunda sp. nov.) and Perspiria species (e.g., P. papillata Vincx \& Gourbault, 1989), (2) the spiral amphideal fovea in Spirodesma is in fact very similar in shape to the cryptospiral amphideal fovea found in some Spirinia species (e.g., S. verecunda sp. nov.) and to the spiral amphideal fovea of Perspiria papillata, and (3) the tail of Spirodesma is conico-cylindrical (as stated in the original description), not conical. In addition, head shape is not a particularly informative trait for differentiating between genera. In our opinion, Spirodesma is most closely related to Perspiria because of the similar buccal cavity (narrow with small or minute teeth), the position of the amphids (only partially surrounded by cuticle annulations), and the shape of the tail (conico-cylindrical). The only difference between these genera appears to be the relative size of the teeth: Perspiria is characterised by a narrow, lightly cuticularised buccal cavity with no or a small/inconspicuous dorsal tooth and no or minute subventral teeth, while Spirodesma is characterised by a narrow, lightly cuticularised buccal cavity with three small, equal teeth. Spirodesma and Perspiria may therefore need to be synonymised in the future as more information becomes available on the former genus.

Stygodesmodora rotundicephala (Cobb, 1920) was originally described as Amphispira rotundicephala and was included in the World Register of Marine Species list of Stygodesmodora species at the time the present study was conducted (WoRMS Editorial Board 2014). The original description, which is based on a single juvenile specimen, clearly shows a head capsule, whereas no amphideal plate was described. Based on the drawing, the specimen/species could possibly belong in Zalonema, but, as the original species description of Amphispira rotundicephala was based only on one juvenile, we regard $A$. rotundicephala Cobb, 1920 to be a species inquirenda.

\section{Acknowledgements}

Funding was provided by NIWA's Coasts and Oceans Centre Research Programme 2 (2013/14 SCI) and the programme 'Impact of Resource Use on Vulnerable Deep-sea Communities' (CO1X0906) and "Consequences of Earth-Ocean Change" (C01X0702). We are grateful to Scott Nodder (NIWA) for facilitating sampling on Chatham Rise (TAN1103), and to Norliana Rosli for processing TAN1004 samples. We also acknowledge the other participants of NIWA voyages TAN1004 and TAN1103, and the officers and crew of RV Tangaroa.

\section{References}

Armenteros M., Ruiz-Abierno A. \& Decraemer W. 2014. Revision of Desmodorinae and Spiriniinae (Nematoda: Desmodoridae) with redescription of eight known species. European Journal of Taxonomy 96: 1-32. http://dx.doi.org/10.5852/ejt.2014.96

Bastian H.C. 1865. Monograph of the Anguillulidae, or free nematoids, marine, land, and freshwater; with descriptions of 100 new species. The Transactions of the Linnean Society of London 25: 73-184.

Blome D. 1982. Systematik der Nematoda eines Sandstrandes der Nordseeinsel Sylt. Mikrofauna des Meeresbodens 86: 1-194.

Boucher G. 1975. Nématodes des sables fins infralittoraux de la Pierre Noire (Manche Occidentale). I. Desmodorida. Bulletin de Muséum National d'Histoire Naturelle 285: 101-128.

Bussau C. 1993. Taxonomische und Ökologische Untersuchungen an Nematoden des Peru-Beckens. $\mathrm{PhD}$ Thesis, Mathematisch-Naturwissenschaftliche Fakultät der Christian-Albrechts-Universität zu Kiel, Germany.

Castro F.J.V., Bezerra T.N.C., Da Silva M.C. \& Fonsêca-Genevois V. 2006. Spirinia elongata, sp. nov. (Nematoda, Desmodoridae) from Pina Basin, Pernambuco, Brazil. Zootaxa 1121: 53-68. 
Cavalcanti M.F., Da Silva M.C., Da Fonsêca-Genevois V. 2009. Spirodesma magdae nov. gen. nov. sp. (Nematoda: Desmodoridae) from the Brazilian deep sea (Campos Basin, Rio de Janeiro, Brazil). Zootaxa 2096: 109-118.

Chitwood B.G. 1936. Some marine nematodes from North Carolina. Proceedings of the Helminthological Society of Washington 3: 1-16.

Cobb N.A. 1920. One hundred new nemas (type species of 100 new genera). Contributions to a Science of Nematology 9: 217-343.

Coles J.W. 1987. Observations on the marine nematode genus Spirinia Gerlach, 1963 (Desmodoridae: Spiriniinae) with descriptions of two new species. Bulletin of the British Museum of Natural History (Zoology) 53: 79-101.

De Coninck L.A. 1943. Sur quelques espèces nouvelles de nématodes libres des eaux et des terres saumâtres de l'Islande. Biologisch Jaarboek 10: 193-220.

De Coninck L.A. 1965. Classe des Nématodes: Systematique des nématodes et sous-classe des Adenophorea. In: Grassé P.P. (ed.) Traité de Zoologie 4: 586-681.

Decraemer W. \& Smol N. 2006. Orders Chromadorida, Desmodorida and Desmoscolecida. In: Abebe E.-A., Transpurger W. \& Andrassy I. (eds) Freshwater Nematodes: Ecology and Taxonomy: 497-573. UK CABI Publishing, Cambridge.

Gerlach S.A. 1953. Recherches sur la faune des eaux interstitielles de Madagascar. III. Sur quelques nématodes libres des eaux souterraines littorales de Madagascar. Mémoires de l'Institut Scientifique de Madagascar 8: 73-86.

Gerlach S.A. 1954. Nouveaux nématodes libres des eaux souterraines littorales françaises. Vie et Milieu 4: 95-110.

Gerlach S.A. 1956. Die Nematodenbesiedlung des tropischen Brandungsstrandes von Pernambuco. Brasilianische Meeres-Nematoden II. Kieler Meeresforschungen 12: 202-218.

Gerlach S.A. 1957. Marine Nematoden von der Kongo-Mündung. Bulletin de l'Institut Royal des Sciences Naturelles de Belgique 33: 1-28.

Gerlach S.A. 1963. Frielebende Meeresnematoden von den Malediven II. Kieler Meeresforschungen 19: 67-103.

Gerlach S.A. 1965. Freilebende Meeresnematoden aus der Gezeitenzone von Spitsbergen. Veröffentlichungen des Instituts für Meeresforschung in Bremerhaven 9: 109-172.

Gerlach S.A. \& Murphy D.G. 1965. Die Familiengruppen-Namen der freilebenden NematodenAdenophorea (Aphasmidia). Zoologischer Anzeiger 175: 211-216.

Inglis W.G. 1968. Interstitial nematodes from St. Vincent's Bay, New Caledonia: Expédition française sur les récifs coralliens de la Nouvelle Calédonie. Editions de la Fondation Singer-Polignac, Occasional Publications 2: 29-74.

Jensen P. 1978. Revision of Microlaimidae, erection of Molgolaimidae fam. n., and remarks on the systematic position of Paramicrolaimus (Nematoda, Desmodorida). Zoologica Scripta 7: 159-173. http://dx.doi.org/10.1111/j.1463-6409.1978.tb00599.x

Leduc D. \& Verschelde D. 2013. One new genus and two new free-living nematode species (Desmodorida, Desmodoridae) from the continental margin of New Zealand, Southwest Pacific Ocean. Zootaxa 3609: 274-290. http://dx.doi.org/10.11646/zootaxa.3609.3.2 
Lorenzen S. 1981. Entwurf eines phylogenetischen Systems der freilebenden Nematoden. Veröffentlichungen des Instituts für Meeresforschung in Bremerhaven, Supplement 7: 1-472.

Luc M. \& De Coninck L.A.P. 1959. Nématodes libres marins de la region de Roscoff. Archives de Zoologie Expérimentale et Générale 98: 108-166.

Maria T.F., Esteves A.M., Smol N., Vanreusel A. \& Decraemer W. 2009. Chromaspirina guanabarensis sp. n. (Nematoda: Desmodoridae) and a new illustrated dichotomous key to Chromaspirina species. Zootaxa 2092: 21-36.

Murphy R.J., Pinkerton M.H., Richardson K.M, Bradford-Grieve J.M. \& Boyd P.W. 2001. Phytoplankton distributions around New Zealand derived from SeaWiFS remotely-sensed ocean colour data. New Zealand Journal of Marine and Freshwater Research 35: 343-362. http://dx.doi.org/10.1080/002 $\underline{88330.2001 .9517005}$

Muthumbi A., Verschelde D. \& Vincx M. 1995. New Desmodoridae (Nematoda: Desmodoroidea): three new species from Ceriops mangrove sediments (Kenya) and one related new species from the North Sea. Cahiers de Biologie Marine 36: 181-195.

Ott J.A. 1977. New freeliving marine nematodes from the West Atlantic. I. Four new species from Bermuda with a discussion of the genera Cytolaimium and Rhabdocoma Cobb, 1920. Zoologischer Anzeiger 198: 120-138.

Silva M.C., Castro F.J.V., Cavalcanti M.F. \& Fonsêca-Genevois V. 2009. Spirinia lara sp. n. and Spirinia sophia sp. n. (Nematoda, Desmodoridae) from the Brazilian continental margin (Campos Basin, Rio de Janeiro). Zootaxa 2081: 31-45.

Somerfield P. \& Warwick R.M. 1996. Meiofauna in Marine Pollution Monitoring Programmes: A Laboratory Manual. Ministry of Ariculture, Fisheries, and Food, Lowestoft, U.K.

Verschelde D. \& Vincx M. 1996. Four new species of the family Desmodoridae (Nematoda, Desmodoroidea) from Kenya. Zoologica Scripta 25: 1-20. http://dx.doi.org/10.1111/j.1463-6409.1996. $\underline{\text { tb00148.x }}$

Verschelde D., Gourbault N. \& Vincx M. 1998. Revision of Desmodora with descriptions of new desmodorids (Nematoda) from hydrothermal vents of the Pacific. Journal of the Marine Biological Association of the United Kingdom 78: 75-112. http://dx.doi.org/10.1017/S0025315400039977

Verschelde D., Nicholas W. \& Vincx M. 2006. A review of the genera Croconema Cobb, 1920 and Pseudochromadora Daday, 1899 (Nematoda, Desmodoroidea): new species from the coasts of Kenya and Australia. Hydrobiologia 571: 17-40. http://dx.doi.org/10.1007/s10750-006-0194-0

Vincx M. \& Gourbault N. 1989. Desmodoridae from the Bay of Morlaix (Brittany) and the Southern Bight of the North Sea. Cahiers de Biologie Marine 30: 103-114.

Vitiello P. 1971. Nématodes libres marins des vases profondes du Golfe du Lion III. Monhysterida, Araeolaimida, Desmodorida. Tethys 2: 647-690.

Warwick R.M. 1970. Fourteen new species of free-living marine nematodes from the Exe estuary. Bulletin of the British Museum of Natural History (Zoology) 19: 137-177.

Wieser W. 1954. Free-living nematodes II. Chromadoroidea. Lunds Universitets Arsskrift, N.F. Avd. 2 50 (16): 1-149.

Wieser W. \& Hopper B. 1967. Marine nematodes of the east coast of North America. I. Florida. Bulletin of the Museum of Comparative Zoology 135: 239-343. 
WoRMS Editorial Board. 2014. World Register of Marine Species. Available from http://www. marinespecies.org [accessed 11 February 2014].

Manuscript received: 3 November 2014

Manuscript accepted: 13 January 2015

Published on: 31 March 2015

Topic editor: Rudy Jocqué

Desk editor: Danny Eibye-Jacobsen

Printed versions of all papers are also deposited in the libraries of the institutes that are members of the EJT consortium: Muséum national d'Histoire naturelle, Paris, France; Botanic Garden Meise, Belgium; Royal Museum for Central Africa, Tervuren, Belgium; Natural History Museum, London, United Kingdom; Royal Belgian Institute of Natural Sciences, Brussels, Belgium; Natural History Museum of Denmark, Copenhagen, Denmark. 